\title{
Analisis Yuridis Putusan Hakim Terhadap Tindak Pidana Penipuan (Studi Putusan Nomor : 70/Pid.B/2020/Pn.Bpd)
}

\author{
Zulkifli1, Tahjul Mila $^{2}$, Yusrizal $^{3}$ \\ ${ }^{13}$ Dosen Fakultas Hukum Universitas Malikussaleh \\ ${ }^{2}$ Mahasiswa fakultas Hukum Unimal \\ Co. A. Email : tahjulmila07@gmail.com
}

\begin{abstract}
This study is to find out the proof of the crime of fraud and to find out the juridical analysis of the judge's decision on the crime of fraud in adjudicating the crime of fraud based on the decision Number: 70/Pid.B/2020/PN.Bpd. One of the laws that regulate social life is criminal law, which regulates all legal rules that determine what regulations against perpetrators of crimes should be imposed on perpetrators. Because basically the purpose of law is to uphold justice so that public order and peace can be realized. From the above description concerning acts or actions that violate the law and are not in accordance with the norms (laws) that have been established, it is a criminal act of fraud as regulated in Article 378 of the Criminal Code. As for this research, it is not an ordinary fraud but a fraud carried out by means of the position given to him so that it can be more burdensome for the perpetrators of criminal acts. In this decision, which is a decision on a criminal case of fraud, is it significant with article 378 of the Criminal Code. This research uses normative juridical research. The sources of legal materials used are primary legal materials and secondary legal materials and tertiary legal materials, and the technique of collecting legal materials in this study is a document or literature research technique (library research). The tool used to collect data in this research is a literature study, the data analysis used is by means of analysis of the interpretation method / legal interpretation in the form of systematic interpretation. Based on the results of the study, conclusions were obtained, namely: First, proof of criminal fraud against cases with Number 70/Pid.B/2020/PN.Bpd. it is in accordance with the formulation of Article 378 of the Criminal Code regarding fraud, through juridical considerations based on the factors revealed in the trial and the facts that are used as the basis for consideration to make a decision against the defendant. Second, in Decision Number: 70/Pid.B/2020/PN.Bpd. The Panel of Judges was not careful in using non-juridical legal considerations and in this case there should be a break in the new law because it was made based on it. In this decision the judge did not prioritize justice for the victim, indeed in the case of fraud there was no restitution for the victim, but at least the judge was more burdensome in punishment to the defendant by imposing a crime under Article 52 of the Criminal Code which explains that an official for committing a crime violates a special obligation from his position , or when he commits a crime, he uses the power, opportunity or means given to him because of his position, the punishment may be increased by one third.
\end{abstract}

Key Words : Fraud, Evidence System, Fraud by position. 


\section{A. PENDAHULUAN}

Saat ini banyak terjadi tindak pidana penipuan, bahkan telah berubah dengan berbagai macam bentuk, perubahan itu terjadi karena semakin tingginya tingkat kecerdasan dari pelaku kejahatan. Nilai-nilai kehidupan masyarakat yang menurun, memiliki peluang tertentu kepada sejumlah masyarakat untuk melakukan suatu tindak pidana yang erat hubungannya dengan kepercayaan dan harta kekayaan, yaitu tindak pidana penipuan. Tindak pidana penipuan merupakan rangkaian kejahatan yang memiliki objek terhadap benda atau barang untuk dimiliki secara pribadi. Penipuan juga termasuk kedalam bentuk mengumbar janji, sifat dasar dari mengumbar janji itu adalah jika orang dibuat keliru, dan oleh karena itu seseorang dengan rela menyerahkan barang atau uangnya. Kejahatan penipuan itu termasuk "materieel delict" artinya untuk kesempurnaannya harus terjadi akibat.

Adapun kasus yang terkait dengan penipuan yaitu kasus yang didakwakan kepada Vina Abdya , yang diatur dan diancam pidana penjara sesuai dengan Pasal 378 KUHP. Dalam kasus ini terdakwa Rovina Septianda yang menyetakkan Publik bukan hanya publik Abdya melainkan sampai publik luar daerah dan menjadi viral dengan sebutan Vina Abdya, dia merupakan oknum mantan sales person pada sebuah Bank Badan Usaha Milik Negara (BUMN) di Blang Pidie, Kabupaten Abdya. Vina menjalankan aksinya dengan cara berinvestasi pada Bank tempat ia bekerja, calon nasabah ditawarkan program investasi dengan keuntungan lebih besar dan bonus menggiurkan dengan keuntungan mencapai $6,25 \%$ perbulan sehingga banyak korban yang tertipu dengan cara mengimingi keuntungan yang didapat dan menyerahkan sejumlah uang untuk di investasi. Bahkan korban mencapai 20 orang yang ikut bersaksi di persidangan, tindak pidana penipuan ini dilakukan terdakwa dalam rentang waktu Juni tahun 2019 hingga Juli tahun 2020. Investasi yang ditawarkan karyawati bank milik 
BUMN itu ternyata bodong, tidak tanggung-tanggung Vina didakwa melakukan tindak pidana penipuan senilai 7,1 miliar lebih. Adapun yang menjadi permasalahan dalam penelitian ini adalah bagaimanakah pembuktiaan tindak pidana penipuan dan bagaimanakah analisis yuridis putusan hakim terhadap tindak penipuan terhadap putusan Nomor : 70/Pid.B/2020/PN.Bpd. tujuan penelitian ini untuk Mengetahui pembuktiaan tindak pidana penipuan dan untuk mengetahui analisis yuridis putusan hakim terhadap tindak pidana penipuan terhadap putusan Nomor: 70/Pid.B/2020/PN.Bpd.

\section{B. METODE PENELITIAN}

Metode penelitian terdiri dari jenis penelitian yuridis normatif yaitu penelitian hukum yang dilakukan dengan cara meneliti berdasarkan peraturan perundang-undangan dengan cara pendekatan perundang-undangan (statute approach) dan pendekatan kasus. Sifat Penelitian ini deskriptif analisis yang bertujuan untuk menggambarkan secara tepat sifatsifat suatu individu, keadaan, gejala atau penyebaran suatu gejala atau frekuensi adanya hubungan tertentu antara suatu gejala dengan gejala lain dalam masyarakat.

Bentuk Penelitian ini termasuk ke dalam penelitian deskriptif yaitu penelitian yang dilakukan guna memberikan gambaran atau merumuskan masalah sesuai keadaan atau fakta yang ada. Sumber bahan hukum dapat dibedakan menjadi 3 (tiga), yaitu bahan hukum primer berupa undang-undang dan putusan, bahan hukum sekunder dan bahan hukum tersier. Teknik pengumpulan data dilakukan melalui teknik penelitian dokumen atau literatur (library research). Alat yang digunakan untuk mengumpulkan data dalam penelitian ini adalah studi kepustakaan, yaitu pengumpulan data dengan cara penelusuran kepustakaan, penelitian kepustakaan yang dilakukan 
dengan cara meneliti sumber bacaan yang berhubungan dengan topik skripsi. Setelah bahan dan sumber terkumpul maka data yang diperoleh dengan metode interpretasi/penafsiran hukum yaitu berupa penafsiran sistematis. Secara sederhana ini disebut sebagai kegiatan memberikan telaah, yang dapat berarti menentang, mengkritik, mendukung, menambah, atau memberi komentar dan kemudian membuat suatu kesimpulan terhadap hasil penelitian dengan pikiran sendiri dan bantuan teori yang telah dikuasai. Dari analisis yang dilakukan kemudian ditarik kesimpulan secara induktif yaitu dengan beranjak dari prinsip khusus kemudian ditarik menjadi kesimpulan umum, yang merupakan jawaban dari permasalahan yang dibahas dan diuraikan secara sistematis.
C. PEMBaHASAN

1. Pembuktian Tindak Pidana Penipuan Terhadap Putusan Nomor 70/Pid.B/2020/Pn.Bpd.

a. Sistem Pembuktian Dalam Perkara Pidana

Proses pembuktian adalah pekerjaan yang paling utama di antara proses panjang penegakan hukum pidana. Pada pekerjaan inilah dipertaruhkan nasib terdakwa dan pada pembuktian inilah titik sentral pertanggungjawaban hakim dalam segala bidang, yakni segi intelektual, moral, ketetapan hukum, dan yang tidak kalah penting ialah segi pertanggungjawabannya kepada Tuhan Yang Maha Esa mengenai amar putusan yang akan diambilnya. Bagaimana amar yang ditetapkan oleh hakim, seluruhnya bergantung pada hasil pekerjaan pembuktian didalam sidang pengadilan (Adami Chazawi, 2005:398).
b. Ketentuan Alat Bukti di Pengadilan

Penipuan merupakan tindak pidana sehingga perbuatan ini disebut delik penipuan. Seseorang dapat disebut telah melakukan tindak pidana penipuan, jika rumusan tindak pidana penipuan telah terpenuhi oleh si pembuat. Delik adalah tindak pidana (strafbaar feit) yaitu tindakan yang 
dilarang dalam hukum pidana semacam itu membuat seseorang menjadi dapat dihukum (P.A.F. Lamintang, 175). Agar dapat dikatakan terpenuhinya delik penipuan, maka unsur-unsur atau elemen-elemen yang harus ada dalam suatu perbuatan itu adalah terdapat kelakuan dan akibat dari perbuatan, hal atau keadaan-keadaan yang menyertai perbuatan, keadaan tambahan yang memberatkan pidana, unsur melawan hukum yang objektif, dan unsur melawan hukum yang subjektif (Moeljatno, 1993:63).

Sifat melawan hukum terdiri dari melawan hukum subjektif dan melawan hukum objektif, Sifat melawan hukum subjektif bergantung pada bagaimana sikap batin si pelaku, Sedangkan sifat melawan hukum objektif bergantung pada pelaksanaan perbuatan yang dilarang oleh hukum (Moeljatno, 1993:69). Dikatakan sebagai sikap melawan hukum materil disamping memenuhi syarat-syarat formil, secara materil perbuatan itu juga harus benar-benar dirasakan oleh masyarakat sebagai perbuatan yang tidak patut atau tercela dan telah dilarang oleh hukum (E.Y. Kanter dan S.R. Sianturi, 1982:125).

Namun dalam penelitian ini penipuan yang dilakukan terdakwa adalah Penipuan yang berkedok investasi atau disebut juga investasi bodong, investasi ini sering dijumpai dalam masyarakat yaitu yang berkaitan dengan praktik pengumpulan dana dari masyarakat sehingga masuk dalam ranah hukum pidana.

Dengan pernyataan di atas dalam membuktikan tindak kejahatan disini yang termasuk penipuan investasi, hukum yang mana yang cocok dijatuhkan kepada terdakwa. Manakala dikatakan kejahatan perusahaan atau kejahatan korporasi (corporate crime), bahwa saat ini korporasi atau badanbadan usaha dalam dunia bisnis dapat diminta pertanggungjawaban pidana atas tindak pidana atau perbuatan melawan hukum yang dilakukan oleh agen-agen korporasi yang bertitik atas nama korporasi tersebut (Marwan Effendy, 2012:166).

Dilihat sudut tindak pidana, penipuan merupakan wujud tindakan yang berunsur rangkaian kebohongan untuk keuntungan diri pelaku, yang berakibat orang yang dibohongi, menjadi dirugikan. Kerugian ini terkait dengan telah memberikan atau menyerahkannya orang lain tersebut atas sesuatu kepada pelaku penipuan. Salah satu tujuan dari para pelaku tindak pidana adalah memperoleh benda atau uang sebagai hasil kejahatan yang mereka inginkan. Tingginya kebutuhan 
hidup yang semakin hari semakin berkembang dan semakin sulit untuk pemenuhannya membuat para pelaku tindak pidana terdorong untuk melakukan tindak pidana untuk memperoleh uang dengan cepat meskipun tindakan mereka tersebut bertentangan dengan nilai-nilai yang ada di masyarakat dan juga dengan peraturan perundangundangan yang berlaku (Widodo Arys Setianto dan Sri Endah W., 2017:332).

Penyebaran berita bohong dan penyesatan merupakan padanan kata yang semakna dengan penipuan. Penipuan dapat dilakukan dengan motivasi, yaitu untuk menguntungkan dirinya sendiri atau paling tidak untuk merugikan orang lain atau bahkan dilakukan untuk menguntungkan dirinya sendiri dan merugikan orang lain secara sekaligus. Dengan motivasi-motivasi tersebut, maka penyebaran berita bohong dan penyesatan dapat dikategorikan sebagai penipuan (Melisa M, 2013:106).

\section{c. Prinsip Pembuktian}

Pembuktian merupakan tahap yang menentukan dalam proses perkara, karena hasil pembuktian dapat diketahui benar atau tidaknya suatu dakwaan atau bantahan tersebut. Dalam rangka penilaian keabsahan penggunaan alat bukti didalam hukum acara pidana terdapat prinsip pembuktian yang dapat memberi pedoman untuk keabsahan suatu pembuktian yaitu terdapat dalam Pasal 183 KUHAP yang menjelaskan Hakim tidak boleh menjatuhkan pidana kepada seseorang kecuali apabila dengan sekurang-kurangnya dua alat bukti yang sah ia memperoleh keyakinan bahwa suatu tindak pidana benar-benar terjadi dan bahwa terdakwalah yang bersalah melakukannya (Gerry Muhammad Rizki, 2017:268).

Meskipun pembuktian merupakan titik strategis di dalam proses peradilan pidana, namun pembuktian itu sendiri adalah sebuah proses yang rawan terhadap pelanggaran HAM, sebab melalui proses sistem pembuktian itulah akan ditentukan apakah kekuatan pembuktian (bewijskracht) dari setiap alat bukti akan menjadikan seorang terdakwa dibebaskan (vrijspraak), dilepaskan dari segala tuntutan, ataukah dipidana. Untuk itulah maka hukum acara pidana bertujuan untuk mencari kebenaran materiil

Proses penemuan bukti-bukti dalam penyelenggaraan peradilan pidana, bukanlah suatu pekerjaan yang mudah, ketidakmudahan itu 
terutama sekali disebabkan karena pekerjaan tersebut mengandung substansi yang lebih dalam lagi daripada hanya sekedar mencari dan mengumpulkan bukti-bukti. Aparat penegak hukum dalam pelaksanaannya akan dihadapkan pada berbagai kondisi yang terletak diseputar perlindungan hak asasi manusia. Namun dalam putusan penipuan investasi ini terjadi ketidakadilan bagi hak asasi manusia dimana tidak terdapat ganti rugi untuk korban yang banyak mengalami kerugian.

2. Analisis Yuridis Putusan Hakim Terhadap Tindak Pidana Penipuan Terhadap Putusan Nomor 70/Pid.B/2020/Pn.Bpd.

Dalam putusannya Hakim menyatakan bahwa Terdakwa terbukti secara yuridis dengan tepat dan benar sesuai fakta hukum yang terungkap di muka sidang sehingga perbuatan materiil Terdakwa telah memenuhi semua unsur tindak pidana melanggar Pasal 378 KUHP jo. Adapun Pasal 55 ayat 1 KUHP jo pasal 64 ayat (1) KUHP menjelaskan bahwa setiap hasil dari kejahatan tindak pidana tidak seharusnya hasil lelang dari barang sitaan dilelang dibagi kepada korban sebagaimana diatur dalam Pasal 39 ayat

(1) KUHPidana dan Pasal 46

KUHAP tersebut bahwa barang-barang kepunyaan terpidana yang diperoleh dari kejahatan dirampas untuk Negara. Namun disini dimana letak keadilan bagi korban yang mengalami banyak kerugian seharusnya berdasarkan hal tersebut, peneliti menyebut hakim harus progresif dan berani menerobos kekakuan hukum dengan tujuan memberikan keadilan.

\section{Pertimbangan Hakim Dalam Menjatuhkan Putusan Nomor 70/Pid.B/2020/PN.Bpd.}

Pertimbangan hakim merupakan salah satu aspek terpenting dalam menentukan terwujudnya nilai dari suatu putusan hakim yang mengandung keadilan (ex aequo et bono) dan mengandung kepastian hukum, disamping itu juga mengandung manfaat bagi para pihak yang bersangkutan sehingga pertimbangan hakim ini harus disikapi dengan teliti, baik dan cermat (Mukti Arto, 2004:140). Hakim tidak dapat menjatuhkan suatu putusan sebelum nyata baginya bahwa peristiwa/fakta tersebut benar-benar terjadi, yakni dibuktikan kebenarannya sehingga nampak adanya hubungan hukum antara para pihak. Mukti Arto, 2004:141) 


\section{Pertimbangan Yuridis}

Pertimbangan yuridis merupakan pertimbangan atau alasan yang menunjukan bahwa peraturan yang dibuat untuk menyelesaikan masalah hukum atau untuk mengisi kekosongan hukum dengan mempertimbangkan aturan yang ada (Sovia Hasanah, 2020). Dalam pertimbangannya, hakim telah memuat putusan yang didakwakan jaksa penuntut umum, keterangan saksi, keterangan terdakwa dan alat bukti sesuai dengan peraturan hukum pidana.

\section{Pertimbangan Sosiologis}

Pertimbangan sosiologis merupakan unsur yang harus memberi manfaat baik kepada pihak yang berperkara maupun masyarakat, karena hukum diciptakan untuk masyarakat dan diharapkan hukum tidak menimbulkan keresahan sosial dalam proses penegakannya (Amran Suadi, 2018:204). Dalam pertimbangannya, hakim tidak melihat keresahan masyarakat yang ditimbulkan dari kasus ini dengan meringankan putusan ini para pelaku kejahatan yang serupa tidak takut atau tidak memberi efek jera kepada pelaku tindak pidana ini.

\section{Pertimbangan Subjektif}

Perbuatan seseorang yang berakibat tidak dikehendaki oleh Undangundang. Sifat unsur ini mengutamakan adanya pelaku (seseorang atau beberapa orang).

Hakim merupakan pilar utama dan tempat terakhir bagi pencari keadilan dalam proses keadilan, sebagai salah satu elemen kekuasaan kehakiman yang menerima, memeriksa dan memutuskan perkara, hakim dituntut untuk memberikan keadilan kepada para pencari keadilan (Mujahid A. Latief, 2007:283). Seorang hakim dalam memutus suatu perkara apalagi perkara pidana harus memiliki kekuatan hukum yang dapat diterima oleh korban dan masyarakat sebagai pemerhati hukum. Berdasarkan hal tersebut tugas hakim harus memikul tanggung jawab yang menjadi suara akal sehat dan mengartikulasikan keadilan dalam dinamika kehidupan masyarakat. Menurut UndangUndang Nomor 48 Tahun 2009 Tentang Kekuasaan Kehakiman, Pertimbangan Hakim adalah pemikiran-pemikiran hakim atau pendapat hakim dalam menjatuhkan putusan dengan melihat hal-hal yang dapat meringankan atau memberatkan pelaku. 
Dalam hal hakim memutuskan suatu perkara hakim harus mengutamakan keadilan bagi pihak korban yang paling di utamakan, apalagi dalam kasus penjatuhan pidana terhadap kasus penipuan yang tidak terdapat restutusi sebagaimana dijelaskan dalam Pasal 378 KUHP yang tidak menjelaskan adanya restitusi bagi korban. Dan hakim seharusnya tidak meringankan terdakwa karena terdakwa melakukan tindak pidana dengan sarana jabatan yang diberikan kepadanya yang merupakan salah satu dasar pemberatan dalam penjatuhan pidana sebagaimana yang dijelaskan dalam Pasal 52 KUHAP yaitu bilamana seseorang pejabat karena melakukan tindak pidana melanggar suatu kewajiban khusus dari jabatannya, atau pada waktu melakukan tindak pidana memakai kekuasaan, kesempatan atau sarana yang diberikan kepadanya karena jabatannya pidananya dapat ditambah sepertiga (Adami Chazawi, 2005:74). Dasar pemberat pidana tersebut dalam Pasal 52 ini terletak pada keaadan jabatan dari kualitas si pembuat (pejabat atau pegawai negeri) mengenai 4 (empat) hal, ialah dalam melakukan tindak pidana dengan :
1. Melanggar suatu kewajiban khusus dari jabatannya;

2. Memakai kekuasaan jabatannya;

3. Menggunakan kesempatan karena jabatannya;

4. Menggunakan sarana yang diberikan karena jabatannya (Adami Chazawi, 2005:75).

Pengadilan semestinya memberikan kepastian hukum kepada para korban untuk mendapatkan ganti rugi. Dan apabila memang akan diadakan perampasan aset maka seharusnya hakim memberikan pertimbanganpertimbangan lain yang memperkuat putusan tersebut dan tidak membuat para korban kehilangan rasa hormat dan rasa percaya kepada para penegak hukum. Selain itu, hakim juga tidak menerobos dengan kekuatan jabatannya karena perkara in casu bukanlah perkara perdata semata akan tetapi sebagaimana fakta hukum yang terungkap di persidangan perkara a quo jelas merupakan perkara tindak pidana, maka seharusnya menurut peneliti karena vonis yang dijatuhkan adalah hukuman pidana, hakim pengadilan pidana semestinya tidak melampaui kewenangannya dan dapat menyerahkan barang bukti aset kepada korporasinya untuk kemudian 
dapat berurusan secara perdata dengan para korban.

Pertimbangan hukum normatif dengan mengabaikan nilai-nilai hukum dan rasa keadilan yang hidup dalam masyarakat, sehingga tak jarang putusan tersebut menimbulkan kontroversi. Akibatnya putusan hakim menunjukkan polarisasi pemikiran yang parsial dimana hakim melahirkan suatu putusan yang tampak benar padahal sebenarnya kurang tepat, serta etis yaitu polarisasi pemikiran yang sangat kontekstual tanpa adanya terobosan hukum dan pragmatis.

Sebagaimana tertuang dalam Pasal 28 Undang-Undang Nomor 4 Tahun 2001 jo Undang-Undang Nomor 48 Tahun 2009 Tentang Kekuasaan 51 Kehakiman, Hakim sebagai pejabat negara dan penegak hukum wajib menggali, mengikuti dan memahami nilai-nilai hukum dan rasa keadilan yang hidup dalam masyarakat serta dalam mempertimbangkan berat ringannya pidana, hakim wajib mempertimbangkan pula sifat yang baik dan jahat dari terdakwa. Sebelum memutus suatu perkara, tentunya hakim melakukan crosscheck terlebih dahulu. Dalam konteks pemeriksaan perkara di muka pengadilan, pertama hakim akan melakukan tindakan, yaitu hakim akan memeriksa mengenai peristiwanya ialah apakah terdakwa telah melakukan perbuatan yang didakwakan; kedua, hakim akan menentukan keputusannya ialah apakah perbuatan yang didakwakan itu merupakan suatu tindak pidana dan apakah terdakwa dapat dipertanggungjawabkan atau bersalah; ketiga, hakim menentukan pidananya apabila memang terdakwa terbukti melakukan tindak pidana dan dapat dipidana (Sudarto, 1986:74).

\section{KESIMPULAN}

Berdasarkan analisis tersebut diatas, dapat ditarik simpulan yaitu Pertama, dalam putusan ini hakim telah mengakomodir prosedur hukum acara pidana, asas-asas umum persidangan, dan telah membuktikan unsur tindak pidana dan kesalahan terdakwa. Namun hakim belum sepenuhnya mengakomodir ketentuan Pasal 24 ayat (1) tentang Kekuasaan Kehakiman, dimana peradilan yang guna meneggakan hukum dan keadilan malah seperti memihak kepada terdakwa dengan mengurangi hukuman yang dituntut oleh jaksa penuntut umum denganmenggunakan alasan non 
yuridis. Selain dari itu, hakim juga tidak menggunakan sumber hukum lain berupa doktrin, yurisprudensi dan nilai-nilai yang hidup dalam masyarakat. Kedua, penulis berargumentasi bahwa putusan Nomor 70/Pid.B/2020/PN.Bpd tidak dapat dikatakan sebagai putusan yang progresif karena hakim tidak menggunakan ketentuan Pasal 52 KUHP tentang pelaku kejahatan melakukan kejahatannya dengan menggunakan kesempatan atau sarana yang diberikan karena jabatan melakukan tindak pidana sehingga dapat memberatkan hukuman terhadap terdakwa.

\section{DAFTAR PUSTAKA}

Ali, Zainudin. 2014. Metode Penelitian Hukum. Jakarta: Sinar Grafika.

Andrisman, Tri. 2011. Delik Tertentu dalam KUHP. Bandar Lampung: Unila.

Bahasa Indonesia, Jakarta: Balai Pustaka.

Bassar, Sudrajat. Tindak-tindak Pidana Dalam KUHP. Jakarta: CV. Remaja Karya.

Bassar, Sudrajat. 1998. Tindaktindak Pidana Dalam KUHP. Jakarta: CV. Remaja Karya.

Chazawi, Adami. 2005. Hukum Pidana Materiil dan Formil. Malang: Bayu Media.
Chazawi, Adami. 2006. Kejahatan

Terhadap Harta Benda. Malang:

Bayu Media.

Departemen Pendidikan dan Kebudayaan. 2008. Kamus Besar Bahasa Indonesia. Balai Pustaka.

Effendy, Marwan. 2012. Kapita Selekta Hukum Pidana, Perkembangan dan Isu-isu Aktual Dalam Kejahatan Finansial dan Korupsi. Jakarta: Referensi.

Fuady, Munir. 2006. Teori Hukum Pembuktian Pidana dan Perdata. Bandung,: Citra Aditya.

Fuady, Munir. 2006. Teori Hukum Pembuktian Pidana dan Perdata. Bandung,: Citra Aditya.

Harahap, M. Yahya. 2006. Pembahasan Permasalahan dan Penerapan KUHAP, Pemeriksaan Sidang Pengadilan, Banding, Kasasi dan Peninjauan Kembali. Jakarta: Sinar Grafika.

Hamzah, Andi. 2010. Delik-delik Tertentu (Speciale Delicten) di Dalam KUHP. Jakarta: Sinar Grafika.

Hamzah, Andi. 1985. Pengantar Hukum Acara Pidana Indonesia. Jakarta: Ghana Indonesia.

Hamzah, Andi. 2008. Asas-Asas Hukum Pidana. Jakarta: PT. Rineka Cipta.

Harahap, M. Yahya. 1993. Pembahasan Permasalahan Dan Penerapan KUHAP Jilid II. Pustaka Kartini.

Hamzah, Andi. Asas-Asas Hukum Pidana. Jakarta: PT. Rineka Cipta. 
Ilyas, Amir. 2012. Asas-Asas Hukum Pidana. Makassar: Rangkang Education dan PuKAP.

Ibrahim, Jhonny. 2008. Teori dan Metodologi Penelitian Hukum Normatif, Malang: Bayumedia.

Kamus Pusat Pembinaan dan Pengembangan Bahasa. 1990. Kamus Besar.

Kanter, E. Y. dan Sianturi, S.R. 1982. Asas-Asas Hukum Pidana di Indonesia dan Penerapannya. Jakarta: Alumni AHM-PTHM.

Muhammad Rizki, Gerry. 2017. KUHP \& KUHAP. Permata Press.

Mulyadi, Lilik. 2007. Hukum Acara Pidana; Normatif, Teoretis, Praktik dan Permasalahannya. Bandung: PT. Alumni.

Marpaung, Ledeng. 2005. Asas Teori Praktik Hukum Pidana. Jakarta: Sinar Grafika.

Muhammad Rizki, Gerry. 2017. KUHP \& KUHAP. Permata Press.

Marwan, M. P., Jimmy, 2009. Kamus Hukum. Surabaya: Realitypublisher.

Muhammad, Abdulkadir. 2004. Hukum Dan Penelitian Hukum. Bandung:Citra Aditya Bakti.

Mulyadi, Lilik, 2007. Hukum Acara Pidana; Normatif, Teoritis, Praktik dan Permasalahannya. Bandung : PT. Alumni.

Moeljatno. 1993. Asas-Asas Hukum Pidana. Jakarta: Rineka Cipta.

Moeljatno. 1993. Asas-Asas Hukum Pidana. Jakarta: Rineka Cipta.

Marzuki, Peter Mahmud. 2005. Penelitian Hukum. Jakarta: Prenadamedia Group.

Nasution, Bahder Johan. 2008. Metode Penelitian Ilmu Hukum. Bandung: Mandar Maju.
Narbuku, Cholid. 1997. Metodologi Penelitian. Semarang: Bumi Aksara.

Prinst, Darwan. 1998. Hukum Acara Pidana Dalam Praktik. Jakarta. Djambatan.

Prodjohamidjojo, Martiman. 1998. Komentar atas KUHAP : Kitab Undang-Undang Hukum Acara Pidana. Jakarta: Pradnya Paramitha.

Prodjokoro, Wirjono. Hukum Acara Perdata Pengadilan Negeri. Jakarta: Sinar Grafika.

S., Ananda. 2009. Kamus Besar Bahasa Indonesi. Surabaya: Kartika.

Sunggono, Bambang. 2003. Metodologi Penelitian Hukum. Jakarta: Raja Grafindo Persada.

Sasangka, Hari dan Rosita, Lili. 2003. Hukum Pembuktian Dalam Perkara Pidana. Bandung: Mandar Maju.

Simorangkir, J.S.T. 1983. Kamus Hukum. Jakarta: Aksara Baru.

Soesilo, R. 1995. Kitab Undangundang Hukum Pidana. Bogor: Politeia.

Subekti, R. 2010. Hukum Pembuktian. Jakarta: Pradnya Paramita.

Sutantio, Retno Wulan dan Oeripkartawinata, Iskandar. 1997. Hukum Acara Perdata Dalam Teori Dan Praktek. Bandung: PT. Alumni.

Siantury, Kanter. 2003 Asas-asas Hukum Pidana Di Indonesia Dan Penerapannya. Jakarta : Storia Grafika. 